\title{
Interactions of rumen chitinolytic bacterium, Clostridium tertium with anaerobic fungi
}

\author{
B Hodrova, J Kopecny \\ Institute of Animal Physiology and Genetics, Czech Academy of Sciences, \\ Prague 10, Uhrineves 104000, Czech Republic
}

The anaerobic fungi were reported as the most effective cellulose degrading microorganisms in the rumen (Wilson and Wood, 1992, Enzyme Microb Technol, 14, 258-264). Similarly to other fungi they have chitin in their cell walls and thus represent a potential substrate for chitinolytic microbes (Orpin, 1977, J Gen Microbiol, 99, 215-218; Gay, 1991, FEMS Microbiol Lett, 80, 99-102).

Chitinolytic enzymes are constituents of all microbial species found in the rumen. The digestive role of these enzymes was recognised in bacteria (Morgavi et al, 1994, Microbiology, 140, 631-636) and protozoa (Widyastuti et al, 1995, Lett Appl Microbiol, 20, 61-64). In contrast, chitinases play mainly a morphogenetic role in fungi. Their presence is essential for normal hyphal growth and branching (Cohen, 1993, Arch Insect Biochem Physiol, 22, 245-261).

In our experiments, we have characterized chitinolytic bacterium $\mathrm{ChK5}$ and its interactions with rumen fungi. Chitinolytic bacteria were found in digesta from both wild and domestic animals. Most were spore forming, Grampositive rods. The isolate ChK5 was identified as Clostridium tertium and further examined. The main chitinolytic activity in this strain was endochitinase $\left(\mathrm{pH}\right.$ optimum 4.5-6.1, $\mathrm{K}_{\mathrm{m}}=19.3$ $\mathrm{mg} / \mathrm{ml}$ ). $N$-acetylglucosimidase ( $\mathrm{pH}$ optimum 7.4) was produced in much lower amount. Optimal conditions for adhesion of this bacterium to colloidal chitin were tested and results are following: $\mathrm{pH} 7.5,100 \mathrm{mM} \mathrm{NaCl}$, $35^{\circ} \mathrm{C}$. Soluble sugars caused significant decrease in the ability to adhere.

The strain ChK5 inhibited fungal cellulose degradation, SCFA production and chitinase activity of Orpinomyces joyonii A4. Similar results were obtained with other species of rumen fungi. Our findings indicate that rumen bacteria with chitinolytic activities may play an important role in controlling growth and activity of rumen fungi. 